NUREG/CR-2413

PNL-4106

\title{
Survey of Remote Area \\ Monitoring Systems at U.S. Light-Water-Cooled Power Reactors
}

Prepared by R. L. Kathren, A. P. Mileham

Pacific Northwest Laboratory

Operated by

Battelle Mernorial Institute

Prepared for

U.S. Nuclear Regulatory

Commission 
This report was prepared as an account of work sponsored by an agency of the United States Government. Neither the United States Government nor any agency thereof, or any of their employees, makes any warranty, expressed or implied, or assumes any legal liability of responsibility for any third party's use, or the results of such use, of any information, apparatus, product or process disclosed in this report, or represents that its use by such third party would not infringe privately owned rights.

The views expressed in this report are not necessarily those of the U.S. Nuclear Regulatory Commission.

\section{Availability of Reference Materiais Cited in NRC Publications}

Most documents cited in NRC publications will be available from one of the following sources:

1. The NRC Public Document Room, 1717 H Street, N.W. Washington, DC 20555

2. The NRC/GPO Sales Program, U.S. Nuclear Regulatory Commission, Washington, DC 20555

3. The National Technical Information Service, Springfield, VA 22161

Although the listing that follows represents the majority of documents cited in NRC publications, it is not intended to be exhaustive.

Referenced documents available for inspection and copying for a fee from the NRC Public Document Poom include NRC correspondence and iriternal NRC memoranda; NRC Office of Inspection and Enforcement bulletins, circulars, information notices, inspection and investigation notices; Licensee Event Reports; vendor reports and correspondence; Commission papers; and applicant and licensee documents and correspondence.

The following documents in the NUREG series are available for purchase from the NRC/GPO Sales Program: formal NRC staff and contractor reports, NRC-sponsored conference proceedings, and NRC booklets and brochures. Also available are Regulatory Guides, NRC regulations in the Code of Federal Regulations, and Nuclear Regulatory Commission /ssuances.

Documents available from the National Technical Information Service include NUREG series reports and technical reports prepared by other federal agencies and reports prepared by the Atomic Energy Commission, forerunner agency to the Nuclear Regulatory Commission.

Documents available from public and special technical libraries include all open literature items, such as books, journal and periodical articles, and transactions. Federal Register notices, federal and state legislation, and congressional reports can usually be obtained from these libraries.

Documents such as theses, dissertations, foreign reports and translations, and non-NRC conference proceedings are available for purchase from the organization sponsoring the publication cited.

Single copies of NRC draft reports are available free upon written request to the Division of Technical Information and Document Control, U.S. Nuclear Regulatory Commission, Washington, DC 20555.

Copies of industry codes and standards used in a substantive manner in the NRC regulatory process are maintained at the NRC Library, 7920 Norfolk Avenue, Bethesda, Maryland, and are available there for reference use by the public. Codes and standards are usually copyrighted and may be purchased from the originating organization or, if they are Arnerican National Standards, from the American National Standards Institute, 1430 Broadway, New York, NY 10018.

GPO Printed copy price: $\$ 3.25$ 
NUREG/CR-2413

PNL-4106

\section{Survey of Remote Area Monitoring Systems at U.S. Light-Water-Cooled Power Reactors}

Manuscript Completed: November 1981

Date Published: April 1982

Prepared by

R. L. Kathren, A. P. Mileham

Pacific Northwest Laboratory

Richland, WA 99352

\section{Prepared for}

Division of Systems Integration

Office of Nuclear Reactor Regulation U.S. Nuclear Regulatory Commission Washington, D.C. 20555

NRC FIN B2174 



\section{ABSTRACT}

A study was made of the capabilities and operating practices, including calibration, of remote area monitoring (RAM) systems at light-water-cooled power reactors in the United States. The information was obtained by mail questionaire. Specific design capabilities, including range, readout and alarm features are documented along with the numbers and location of detectors, calibration and operational procedures. Comments of respondents regarding RAM systems are also included. 

The capabilities of remote area monitoring systems at U.S. light-watercooled power reactors were evaluated from responses to a mailed questionnaire completed by 55 plants representing $81 \%$ of the operating license holders. Boiling water reactors (BWRs) had more remote detectors than pressurized water reactors (PWRs), 35 versus 20, respectively, with Geiger-Muelier (G-M) tubes predominating. The readouts were logarithmic in units of exposure rate. Relatively few respondents reported that their plants had upper limit capability in excess of $10^{4} \mathrm{R} / \mathrm{hr}$, even for systems used to monitor levels in containment. Visual alarms varied in color, with red predominating in PWRs and yellow/orange in BWRs. Steady state lights were preferred. All plants had local alarms. Operational and calibration checks were variable among the plants participating in the study. Most plants used a radioactive source to perform operational checks and calibrations, with the frequency dependent on plant type. Nearly a11 PWR respondents reported that operational checks were performed at least monthly, while less than half of the BWR respondents reported the same frequency. Respondents were generally pleased with the performance of their systems, although several desired additional capabilities such as readout in the health physics office (PWRs only), recorders, digital readouts, and computer capability. Detailed response data on a variety of design and operating features are tabulated and evaluated, and a comparison is made between the two types of light-water reactors. 
' 


\section{CONTENTS}

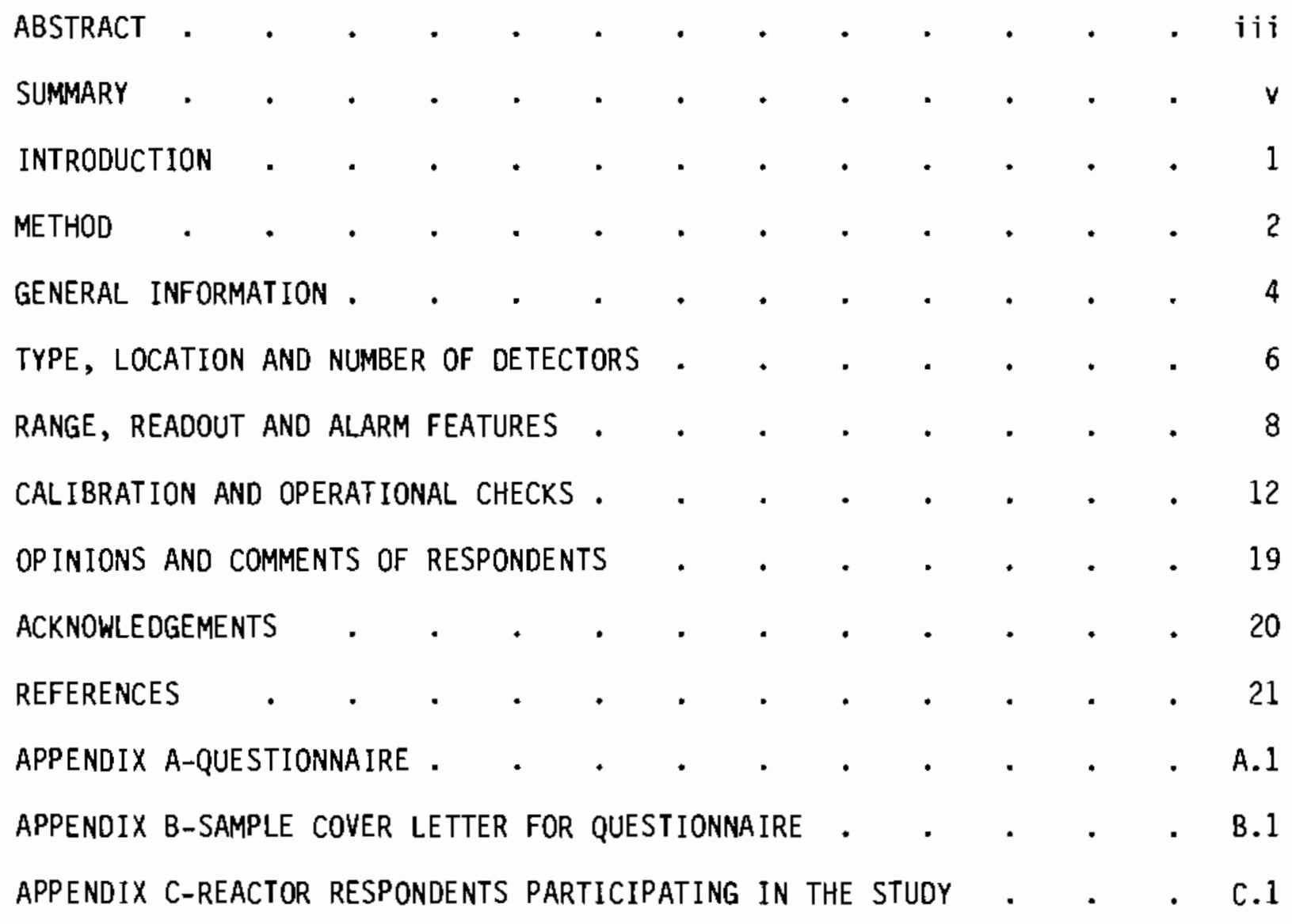




\section{TABLES}

1 Manufacturers of Remote Area Monitoring Systems Used in Commercial Light Water Reactor Plants . . . . . . . . 4

2 Type and Number of Detectors by Location in BWRs . . . . 7

3 Type and Number of Detectors by Location in PWRs . . . . 7

4 Readout Locations for Containment RAMs . . . . . . . 9

5 Visual High-Level-Radiation Alarms in BWR Control Rooms . . 10

6 Visual High-Level-Radiation Alarms in PWR Control Rooms . . . 10

7 Visual Local High-Level-Radiation ATarms in BWRs . . . . . 11

8 Visual Local High-Level-Radiation Alarms in PWRs . . . . . 11

$g$ Frequency of Operational Checks of RAMs in BWRs . . . . $~ . ~ 13$

10 Frequency of Operational Checks of RAMs in PWRs . . . . 13

11 Methods of Routine Operational RAM Checks a: BWRs . . . . 14

12 Methods of Routine Operational RAM Checks a: PWRs . . . . 15

13 Specific Calibration Functions Performed on RAMs by Plant Location 18 


\section{INTRODUCTION}

Remote area monitors (RAMs), also known as area radiation monitors (ARMs), are used to measure ambient radiation levels on a continuous basis. A RAM system consists of one or more radiation detectors hard-wired to a readout assembly in another location or room, perhaps several hundred feet away. Local readout may also be provided at or near the detector. RAM systems may also be equipped with a variety of other features, including local and remote alarm capability, to indicate when a preset radiation level has been reached or exceeded, internal calibration capability, and logarithmic or autoranging readout to make them useful over a wider range.

Important applications of RAMs include continuous monitoring in areas with actual or potential high ambient radiation levels and surveillance of radiological conditions without exposure of personnel. They are also useful for determining exposure rates prior to personnel entry and for post-accident evaluation. Thus, RAM systems are used at power reactors to monitor ambient photon exposure rates inside containment, as well as in other remote locations.

Despite the utility of RAM systems in nuclear power plants, the capabilities and design features of systems currently in use are not well known. Certain criteria have been established over the years (Selby et al. 1974; ANSI 1979) and attention was further focused on the capabilities of these instruments following the accident at the Three Mile Island Nuclear Station (NRC 1979; Lahti 1980). Accordingly, the Pacific Northwest Laboratory, (a) in response to a request from the Nuclear Regulatory Commission, undertook a study to document some of the more salient features of RAMs installed in operating power reactors in the United States.

(a) Operated for U.S. Department of Energy by Battelle Memorial Institute. 
METHOD

A direct-mail questionnaire was selected as the most direct and efficient way to obtain detailed information regarding installed RAM systems at comercial nuclear power plants. Onsite inspection was rejected as too costly and time consuming, and review of licensing documents revealed little specific information of direct relevance. The goal was to develop a relatively simple unambiguous questionnaire that could be answered in approximately 30-45 minutes by an individual such as the plant health physicist who would be concerned with, and presumably knowledgeable of, the RAM systems used in the plant. An extensive preliminary questionnaire was first developed, based on established performance criteria (ANSI 1979; NRC 1979; Selby et a1. 1974) and included substantive and numerous questions regarding RAM system operation, maintenance, calibration, design and installation. This lengthy questionnaire was reduced in size by elimination of items of secondary importance, based in part on discussions with members of the NRC health physics appraisal team and other professionals involved with RAM design and operation.

A draft questionnaire was prepared in conjunction with social scientists from the Battelle Human Affairs Research Center and pretested on health physics appraisal personnel familiar with instrumentation at specific reactors to check for ambiguity and the time required for completion. The final questionnaire (Appendix A) included coding for computerized retrieval of responses and requested information on compliance and requirements put forth following the TMI-2 accident (NRC 1979).

Questionnaires were sent by first class mail to all NRC-licensed operating light water power reactors along with a brief explanatory cover letter (Appendix B) and a preaddressed paid return envelope. The one gas-cooled power reactor with an operating license was excluded from the survey because of its uniqueness. Initially, the response was slower and smaller than anticipated. Only about half of the questionnaires originally sent out were returned within four weeks of the requested return date, some with brief cover letters or notes offering additional help if needed, or apologizing for the delay in return. Those not responding by this date were contacted by telephone, which produced a 
few additional responses. Fourteen licensees involving a total of 29 operating plants claimed to have not received or misplaced the questionnaire and were sent a second mailing by certified mai1. Ultimately, returns were received from 55 of 68 licensed plants (81\%), providing data on 17 BWRs and 38 PWRs. The list of participating plants is given in Appendix $C$. 


\section{GENERAL INFORMATION}

Data from the completed questionnaires were totaled, collated, and evaluated by reactor type (i.e., BWR or PWR). An attempt was made to correlate certain specific operating characteristics with age or electrical output of the plant, but in general no correlation was found. Responses were typically prepared by members of the plant staff, usually by a health physicist or other member of the radiation protection staff. However, about one-fourth of the responses were prepared by corporate staff pensonnel, this being particularly the case with multiple plant licensees. In a few cases, the person(s) completing the questionnaire were not identified.

Al) plants responding reported the use of one or more installed commer cially available RAM systems, although these were not always used as containment monitors. Certain patterns were evident with regard to the choice of manufacturer. A total of 91 separate systems manufactured by 10 different companies were reported in the 55 plants, as shown in Table 1 . Three

TABLE 1. Manufacturers of Remote Area Monitoring Systems Used in Commercial Light Water Reactor Plants

\begin{tabular}{|c|c|c|c|c|c|c|}
\hline \multirow[b]{2}{*}{ Manuf acturer } & \multicolumn{2}{|c|}{$\begin{array}{c}\text { A } 11 \text { Plants } \\
(\mathrm{N}=55)\end{array}$} & \multicolumn{2}{|c|}{$\begin{array}{c}\text { BWRs } \\
(\mathrm{N}=17)\end{array}$} & \multicolumn{2}{|c|}{$\begin{array}{c}\text { PWRS } \\
(N=38) .\end{array}$} \\
\hline & Number & Percent & Numper & Percent & Number & Percent \\
\hline Eberline & 1 & 1 & & & 1 & 2 \\
\hline General Atomic & 21 & 23 & & & 21 & 40 \\
\hline General Electric & 30 & 33 & 31) & 77 & & \\
\hline NMC & 7 & 8 & 2 & 5 & 5 & 10 \\
\hline NRC & 1 & 1 & & & 1 & 2 \\
\hline Nuclear Industries & 1 & 1 & & & 1 & 2 \\
\hline Tracerlab & 10 & 11 & 2 & 5 & 8 & 15 \\
\hline Tracor & 2 & 2 & 2 & 5 & & \\
\hline Victoreen & 17 & 19 & 3 & 8 & 14 & 27 \\
\hline Westinghouse & 1 & 1 & -- & $\ldots$ & 1 & 2 \\
\hline Total & 91 & 100 & 39 & 100 & 52 & 100 \\
\hline
\end{tabular}


manufacturers have supplied more than three-fourths of the RAMs currently in use. BWRs employ primarily General Electric RAM instrumentation, which is not too surprising in that GE is also the manufacturer of BWRs and hence can "marry" various systems. Two manufacturers--General Atomic and Victoreen--have supplied most of the RAMs to the PWRs, with Tracerlab a distant third. General Atomic installations are generally more recent than others, which could be attributed to upgrading or retrofitting programs to meet the specifications put forth in NUREG-0578 (NRC 1979) or the NRC Regulatory Guide 1.97 (NRC 1980).

About a third of the plants--14 PWRs and 4 BWRs--indicated that they were either in the process of or contemplating upgrading their monitoring systems. All but one cited regulatory requirements as the reason; four cited inadequate capability in lieu of or in addition to the regulatory requirement. 


\section{TYPE, LOCATION AND NUMBER OF DETECTORS}

The type, number, and location of detectors in the plants are given in Tables 2 and 3 for BWRs and PWRs. The data imply considerable homogeneity among the BWRs, which use Geiger-Mueller detectors exclusively. This homogeneity is not unexpected, as most of the RAM systems in BWRs were supplied by the Nuclear Steam Supply System vendor (Table 1). However, more detailed examination of the data revealed that of the 17 BWR plants five reported no detectors in containment. (These plants may in fact have RAMs in containment, but chose not to report this fact.)

The remaining 12 plants showed considerable variability in the number of detectors in containment, the range being 2 to 24 with a mean \pm standard deviation of 15.1+5.9. Similar variability of numbers was also observed for the other locations. In part, this variability may be due to the nomenclature because the terminology differs to some extent among BWR and PWR operators. Some BWR respondents qualified location with the adjective "secondary" when referring to containment, or considered the reactor building to be synonymous with containment.

Overa 11, BWRs had more detectors in their plants than PWRs-35 vs. 20, respectively. Although PWRs did show a greater diversity of type of detector, G-Ms accounted for nearly three-fifths of the total. On the average, PWRs had on ly 3.1 detectors in containment (one plant had more than 8) compared with 11.3 in auxiliary buildings, which in many units is where fuel storage and handling is accomplished. Again, the problem of nomenclature and variation in plant structures may have contributed to the diversity of the response. 
TA8LE 2. Type and Number of Detectors by Location in BWRs

\begin{tabular}{|c|c|c|c|c|c|c|c|c|}
\hline \multirow[b]{2}{*}{$\begin{array}{l}\text { Type of } \\
\text { Detector }\end{array}$} & \multicolumn{7}{|c|}{ Number at Location Specified } & \multirow[b]{2}{*}{$\begin{array}{r}\% \text { of } \\
\text { Total }\end{array}$} \\
\hline & Contajnment & $\begin{array}{l}\text { Auxiliary } \\
\text { Building }\end{array}$ & $\begin{array}{c}\text { Fuel } \\
\text { Handling }\end{array}$ & $\begin{array}{l}\text { Turbine } \\
\text { Generator }\end{array}$ & $\begin{array}{c}\text { Contro1 } \\
\text { Room }\end{array}$ & Other & $\begin{array}{l}\text { Total No. } \\
\text { of Type }\end{array}$ & \\
\hline$G-M$ & 181 & 102 & 103 & 46 & 115 & 28 & 575 & $97 \%$ \\
\hline Ion chamber & 0 & 0 & 0 & 1 & 0 & 0 & 1 & $0.2 \%$ \\
\hline Scintilation & 2 & 6 & 2 & 0 & 0 & 7 & 17 & $3 \%$ \\
\hline other & $\underline{0}$ & 0 & $\underline{0}$ & $\underline{0}$ & 0 & $\underline{0}$ & $\underline{0}$ & 0 \\
\hline Total & 183 & 108 & 105 & 47 & 115 & 35 & 593 & $100 \%$ \\
\hline
\end{tabular}

TABLE 3. Type and Number of Detectors by Location in PWRs

\begin{tabular}{|c|c|c|c|c|c|c|c|c|}
\hline \multirow[b]{2}{*}{$\begin{array}{l}\text { Type of } \\
\text { Detector }\end{array}$} & \multicolumn{7}{|c|}{ Number at Location Specified } & \multirow[b]{2}{*}{$\begin{array}{l}\text { \% of } \\
\text { Total }\end{array}$} \\
\hline & Containment & $\begin{array}{l}\text { Auxiliary } \\
\text { Building }\end{array}$ & $\begin{array}{c}\text { Fue } \\
\text { Handling }\end{array}$ & $\begin{array}{l}\text { Turbine } \\
\text { Generator }\end{array}$ & $\begin{array}{c}\text { Control } \\
\text { Room } \\
\end{array}$ & Other & $\begin{array}{l}\text { Total No. } \\
\text { of Type }\end{array}$ & \\
\hline$G-M$ & 65 & 250 & 40 & 29 & 23 & 23 & 430 & $57 \%$ \\
\hline Ion chamber & 40 & 97 & 14 & 10 & 10 & 10 & 181 & $24 \%$ \\
\hline Scintilation & 10 & 84 & 23 & 6 & 8 & 12 & 143 & $19 \%$ \\
\hline Other & $\underline{0}$ & 0 & $\underline{0}$ & $\underline{0}$ & $\underline{0}$ & $\underline{0}$ & 1 & $0 \%$ \\
\hline Total & 116 & 431 & 77 & 44 & 41 & 45 & 755 & $100 \%$ \\
\hline
\end{tabular}


RANGE, READOUT AND ALARM FEATURES

Plants un iformly reported logarithmic readout over several decades in units of $\mathrm{mR} / \mathrm{hr}$ or $\mathrm{R} / \mathrm{hr}$, with the exception of one PWR that reported a multiscale linear readout. All BWR respondents reported the readout in units of $\mathrm{mR} / \mathrm{hr}$, and in two cases, counts per minute $(\mathrm{cpm})$ as well. At PWRs, $\mathrm{mR} / \mathrm{hr}$ predominated, with $\mathrm{R} / \mathrm{hr}$ used primarily for the higher range instruments located in containment or auxiliary buildings.

Ranges were highly variable and seemingly unrelated to the plant's age or power level. The upper limit of any RAM in a BWR was $1,000 \mathrm{R} / \mathrm{hr}\left(10^{6} \mathrm{mR} / \mathrm{hr}\right)$. These RAMs were all located in containment of two pairs of similar plants that began commercial operation in the mid-1970's. For the remaining eight plants reporting containment monitors, the upper limit wès $10 \mathrm{R} / \mathrm{hr}$ or less.

Among the PWRs, high ranges were generally greater for monitors located in containment. Several reported containment RAM systems with a capability to $10^{6} \mathrm{R} / \mathrm{hr}$ or greater; five reactors (four operated by a single company) reported a capability to $10^{7} \mathrm{R} / \mathrm{hr}$. In general, the maximum capability in auxiliary buildings or containment did not exceed $10^{4} \mathrm{R} / \mathrm{hr}$ and in several plants was reported as $1 \mathrm{R} / \mathrm{hr}$ or less.

Readout locations for RAMs in containment (Table 4) showed little difference between reactor type. The percentages cited in the table are based on the 52 (of 55) returns in which the question was answered. This, coupled with the fact that on ly $80 \%$ of the operating reactor respondents returned data, shows that the results are based on returns from only three-fourths of the operating reactors. The results must thus be interpreted accordingly, and it may well be that bias exists. This caveat regarding potential bias and data interpretation holds for other results as well.

Examination of Table 4 reveals that most of the plants reporting had local and control room readout, but few had readouts in either the health physics 
TABLE 4. Readout Locations for Containment RAMs

\begin{tabular}{|c|c|c|c|c|c|c|}
\hline \multirow[b]{2}{*}{ Location } & \multicolumn{2}{|c|}{$\begin{array}{c}\text { All P1ants } \\
(N=52)\end{array}$} & \multicolumn{2}{|c|}{$\begin{array}{c}\text { BWRs } \\
(N=17)\end{array}$} & \multicolumn{2}{|c|}{$\begin{array}{c}\text { PWRs } \\
(N=35)\end{array}$} \\
\hline & Number & Percent & Number & Percent & Number & Percent \\
\hline Local & 42 & 81 & 14 & 76 & 28 & 80 \\
\hline Control room & 48 & 92 & 14 & 76 & 34 & 97 \\
\hline Health physics office & 2 & 4 & 0 & 0 & 2 & 6 \\
\hline $\begin{array}{l}\text { Emergency operations } \\
\text { center }\end{array}$ & 5 & 10 & 0 & 0 & 5 & 14 \\
\hline Other & 3 & 6 & 1 & 1 & 3 & 9 \\
\hline
\end{tabular}

NOTE: Percentage is of those responding to the question; not all respondents answered this question.

office or emergency operations center. None of the BWRs reported a readout in the emergency operations center (EOC), and only 14\% of the PWRs had a readout in this key location. A few plants did indicate that they were in the process of adding RAM readouts to the EOC.

About three-fourths of the plants reported having a chart recorder for the readout of the RAM system used to monitor in containment, the fraction being somewhat greater among the PWRS. Only seven plants reported computer capabilities for the containment RAM systems, and only six of the 55 plants in the survey--3 each BWRs and PWRs--claimed to meet the requirements of NUREG 0578.

While RAM readout (i.e., the means to monitor the exposure rate) was not provided in all control rooms, high-level-radiation alarms were audible in all but one case (98\%). In addition all but one reported one or more visual highlevel-radiation alarms. There was considerable diversity with regard to the type and color of visual alarms, as shown in Tables 5 and 6 . Despite the diversity, there is a clear lack of preference for magenta-colored and flashing or rotating lights. Indeed, red lights were most common in PWRs, with BWRs showing a slight preference for yellow/orange. Overall, 35 of the 54 plants reporting indicated more than one visual high-level-radiation alarm. 
TABLE 5. Visual High-Level-Radiation Alarms in BWR Control Rooms Number (\%) Reporting

\begin{tabular}{|c|c|c|c|c|c|}
\hline Type & Red & Magenta & Yellow/Orange & White & other \\
\hline $\begin{array}{l}\text { Flashing or } \\
\text { rotating light }\end{array}$ & --- & $3(18 \%)$ & -- & $4(24 \%)$ & --- \\
\hline Steady light & $4(24 \%)$ & $3(18 \%)$ & $4(24 \%)$ & $3(18 \%)$ & --- \\
\hline $\begin{array}{l}\text { Pilot light } \\
\text { on control panel }\end{array}$ & $2(12 \%)$ & --- & $6(35 \%)$ & $1(6 \%)$ & $1(6 \%)$ \\
\hline
\end{tabular}

NOTE: 1) Number in Sample $=16$; one plant failed to report the type of visual al arm.

2) $9(53 \%)$ reported more than one visuall alarm; 4 with 2 and 5 with 3 .

TABLE 6. Visual High-Level-Radiation Alarms in PWR Control Rooms

\begin{tabular}{|c|c|c|c|c|c|}
\hline \multirow[b]{2}{*}{ Type } & \multicolumn{5}{|c|}{ Number (\%) Reporting } \\
\hline & Red & Magenta & Yellow/Orange & White & other \\
\hline $\begin{array}{l}\text { Flashing or } \\
\text { rotating light }\end{array}$ & $4(11 \%)$ & -- & $1(3 \%)$ & $9(24 \%)$ & $3(8 \%)$ \\
\hline Steady light & $25(66 \%)$ & --- & $2(5 \%)$ & $4(11 \%)$ & -- \\
\hline $\begin{array}{l}\text { Pilot light } \\
\text { on control panel }\end{array}$ & $22(58 \%)$ & $-\cdots$ & $2(5 \%)$ & $5(13 \%)$ & -- \\
\hline
\end{tabular}

NOTE: 1) Number in Sample $=38$.

2) 26 (68\%) reported more than one visual alarm; 16 with 2 and 7 with 3 , and 3 with 4.

The situation was similar with regard to local alarms. All plant respondents reported local (i.e. near the detector) high-level-radiation alarms, with all but three having both visual and audible alarms. Two reported audible alarms only. As with the control room, there was a decided preference for steady lights, almost exclusively red in the case of PWRs and a mixture of colors in the case of BWRs (Tables 7 and 8 ).

A similar lack of uniformity was reported for high-level-radiation alarms located elsewhere in the plant. In general, both audible and visual alarms were provided, again with red the most commonly used color at PWRs and yellow/ orange at BWRs. 
TABLE 7. Visual Local High-Level-Radiation Alarms in BWRs

\begin{tabular}{|c|c|c|c|c|c|}
\hline \multirow[b]{2}{*}{ Type } & \multicolumn{5}{|c|}{ Number $(\%)$ Reporting } \\
\hline & Red & Magenta & Yellow/Orange & White & Other \\
\hline $\begin{array}{l}\text { Flashing or } \\
\text { rotating light }\end{array}$ & --- &.- & -- & --- & --- \\
\hline Steady light & $3(18 \%)$ & --- & $11(65 \%)$ & --- & --- \\
\hline $\begin{array}{l}\text { Pilot light } \\
\text { on control panel }\end{array}$ & $2(12 \%)$ & --- & $3(18 \%)$ & $3(18 \%)$ & --- \\
\hline
\end{tabular}

NOTE: Number Reporting $=17 ; 7$ have visual alarms.

TABLE 8. Visual Local High-Level-Radiation Alarms in PWRs

\begin{tabular}{|c|c|c|c|c|c|}
\hline \multirow[b]{2}{*}{ Type } & \multicolumn{5}{|c|}{ Number $(\%)$ Reporting } \\
\hline & Red & Magenta & Yellow/Orange & White & 0ther \\
\hline $\begin{array}{l}\text { Flasting or } \\
\text { rotating light }\end{array}$ & $5(13 \%)$ & -- & $1(3 \%)$ & -- & $\ldots$ \\
\hline Steady light & $35(92 \%)$ & $\cdots$ & $1(3 \%)$ & $1(3 \%)$ & -- \\
\hline $\begin{array}{l}\text { Pilot light } \\
\text { on control pane } 1\end{array}$ & $16(42 \%)$ & --- & $1(3 \%)$ & -- & $1(3 \%)$ \\
\hline
\end{tabular}

NOTE: Number Reporting $=38 ; 50 \%$ have two or more visual alarms.

About two-thirds of the respondents (36) reported latching alarms-i.e. alarms that remain on unless acknowledged even though the radiation level has dropped below the alarm point. Only 12 plants had intermediate-level alarms on the ir RAM systems. 


\section{CALIBRATION AND OPERATIONAL CHECKS}

Operational checks of RAM systems were performed with varying frequency, and, in three plants, not done at all. In general, the frequency of the check was the same for all RAMs, irrespective of location in the plant. Thus, if the plant reported a weekly checking frequency for RAMs in containment, this same frequency applied to RAMs in the auxiliary building, control room, or wherever.

Comparison of Tables 9 and 10 reveals a striking difference in the frequency of operational checks at BWRs and PWRs. This is not wholly unexpected in view of the great design differences and operating philosophies of the two types of plants. For example, BWR containmen: entries are rare relative to PWR entries; in general it is more difficult to enter a BWR containment building during operation. Hence, operational checks would be expected at less frequent intervals in BWRs, unless these were somehow done remotely, as by internal test circuitry.

The modality by which operational checks are performed is shown in Tables 11 and 12 for BWRs and PWRs. Most plants used more than a single method, as evidenced by the fact that the total percentages for any location are greater than 100 . Inspection of the tables also reveals that multiple operational checks were more likely to be done at PWRs.

Considering only RAMs in containment, we found that five (38\%) of the BWRs and seven (19\%) of the PWRs relied on a single method of operational checking. At two of the BWRs, this was an internal test circuit, which, of course, does not necessarily check the detector. Two of the remaining three BWRs used an internal radioactive check source, and the other used an external source. At the PWRs, five used an internal radioactive check source, and the other two relied exclusively on visual checks. The mos: commonly reported combinations involved checking with a radioactive source plus the use of an external signal generator or internal test circuit.

Forty-two of the 49 plants responding reported using a radioactive source to make routine operational checks. About a third (17) used an internal source alone with one out of seven, or seven in total, using only an external check 
TABLE 9. Frequency of Operational Checks of RAMs in BWRS

\begin{tabular}{|c|c|c|c|c|c|c|c|c|}
\hline \multirow[b]{2}{*}{$\begin{array}{l}\text { Location } \\
\text { of RAM }\end{array}$} & \multicolumn{8}{|c|}{ Number and (\%) Reporting } \\
\hline & $\begin{array}{l}\text { Total } \\
\text { Reporting }\end{array}$ & Week ly & Monthly & Quarterly & $\begin{array}{c}\text { Semi- } \\
\text { Annualiy }\end{array}$ & Annual1y & Irregularly & $\begin{array}{l}\text { Not } \\
\text { Done }\end{array}$ \\
\hline Containment & 15 & $2(13 \%)$ & $3(20 \%)$ & $5(33 \%)$ & $1(7 \%)$ & $4(27 \%)$ & --- & --- \\
\hline Auxiliary building & 14 & $2(14 \%)$ & $3(21 \%)$ & $3(21 \%)$ & $4(29 \%)$ & $2(14 \%)$ & -- & --- \\
\hline $\begin{array}{c}\text { Fuel handling } \\
\text { building }\end{array}$ & 13 & $2(15 \%)$ & $4(31 \%)$ & $4(31 \%)$ & $1(8 \%)$ & $2(15 \%)$ & -- & $\ldots$ \\
\hline $\begin{array}{l}\text { Turbine-Generator } \\
\text { room }\end{array}$ & 15 & $2(13 \%)$ & $4(27 \%)$ & $5(33 \%)$ & $2(13 \%)$ & $2(13 \%)$ & -- & -- \\
\hline Control room & 15 & $2(13 \%)$ & $4(27 \%)$ & $5(33 \%)$ & $2(13 \%)$ & $2(13 \%)$ & --- & -- \\
\hline
\end{tabular}

TABLE 10. Frequency of Operational Checks of RAMs in PWRs

ம

\begin{tabular}{l}
$\begin{array}{c}\text { Location } \\
\text { of RAM }\end{array}$ \\
\hline Containment \\
Auxiliary building \\
Fuel handling \\
building \\
Turbine-Generator \\
room \\
Control room
\end{tabular}

\begin{tabular}{|c|c|c|c|c|c|c|c|}
\hline $\begin{array}{c}\text { Total } \\
\text { Reporting }\end{array}$ & Week $7 y$ & Monthiy & Quarterly & $\begin{array}{c}\text { Semi- } \\
\text { Annually }\end{array}$ & Annually & Irregular ly & $\begin{array}{l}\text { Not } \\
\text { Done }\end{array}$ \\
\hline 34 & $16(47 \%)$ & $14(41 \%)$ & $1(3 \%)$ & -- & $1(3 \%)$ & $2(6 \%)$ & -- \\
\hline 35 & $16(46 \%)$ & $16(46 \%)$ & $1(3 \%)$ & $-n$ & $1(3 \%)$ & -- & $1(3 \%)$ \\
\hline 34 & $16(47 \%)$ & $17(50 \%)$ & $1(3 \%)$ & --- & -- & $\ldots$ & $\cdots$ \\
\hline 24 & $11(46 \%)$ & $11(46 \%)$ & $1(3 \%)$ & -- & - & -- & $1(3 \%)$ \\
\hline 31 & $14(45 \%)$ & $14(45 \%)$ & $1(3 \%)$ & -- & $1(3 \%)$ & -- & $1(3 \%)$ \\
\hline
\end{tabular}

NOTE: Three plants failed to answer this question. 
TABLE 11. Methods of Routine Operational RAM Checks at BWRs

\begin{tabular}{|c|c|c|c|c|c|c|c|}
\hline \multirow[b]{2}{*}{ RAM Location } & \multicolumn{7}{|c|}{ Number and (\%) Using } \\
\hline & $\begin{array}{c}\text { Internal } \\
\text { Radioactive } \\
\text { Source } \\
\end{array}$ & $\begin{array}{c}\text { External } \\
\text { Radioactive } \\
\text { Source } \\
\end{array}$ & $\begin{array}{c}\text { Internal } \\
\text { Electronic } \\
\text { Circuit } \\
\end{array}$ & $\begin{array}{l}\text { Light } \\
\text { Source }\end{array}$ & $\begin{array}{c}\text { External } \\
\text { Signal } \\
\text { Generator } \\
\end{array}$ & $\begin{array}{c}\text { Visual } \\
\text { Inspection } \\
\end{array}$ & Other \\
\hline Containment & $5(38 \%)$ & $8(62 \%)$ & $5(38 \%)$ & --- & $2(15 \%)$ & $5(38 \%)$ & --- \\
\hline Auxiliary building & $7(54 \%)$ & $9(69 \%)$ & $7(54 \%)$ & --- & $2(15 \%)$ & $8(62 \%)$ & --- \\
\hline $\begin{array}{l}\text { Fuel handling } \\
\text { facility }\end{array}$ & $8(62 \%)$ & $11(85 \%)$ & $5(38 \%)$ & --- & $2(15 \%)$ & $8(62 \%)$ & -- \\
\hline $\begin{array}{l}\text { Turbine-Generator } \\
\text { room }\end{array}$ & $8(62 \%)$ & $12(92 \%)$ & $5(38 \%)$ & -- & $2(15 \%)$ & $8(62 \%)$ & -- \\
\hline Control room & $8(62 \%)$ & $12(92 \%)$ & $5(38 \%)$ & --- & $2(15 \%)$ & $8(62 \%)$ & --- \\
\hline
\end{tabular}

Number in sample $=13$. 
TA8LE 12. Methods of Routine Operational RAM Checks at PWRs

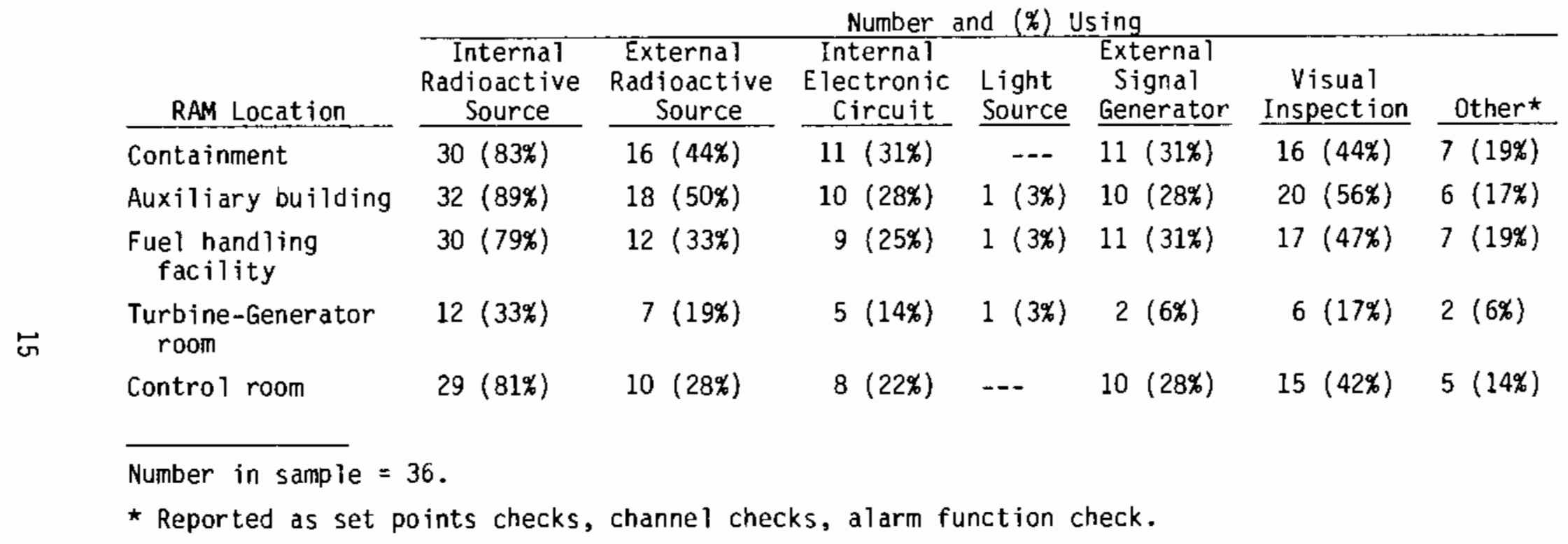


source. About one-third (17) reported using both types of radioactive sources, while, as noted above, one in seven did not use any radioactive source at all.

An important way of verifying the operability of RAMs is to use some means to provide a positive reading at all times, sice a zero or lower peg indication as from a logarithmic scale might be a result of malfunction rather than from low radiation levels. At BWRs, this was accomplished with an internal radioactive source, either singly (four plants) or in conjunction with background radiation (nine plants), at 13 of the 17 plants. Three of the remaining four plants used background radiation levels alone; electronic means were used at the other plant. About two-fifths of the PWRs (16) used background radiation alone for this purpose, with three plants using internal radioactive sources. Only one plant used electronic means exclusively; eight plants used a combination of radiation background and an internal source; and two plants combined background radiation levels with electronic methods. Four plants used all three methods--internal source, background radiation, and electronic means--and one respondent did not specify the method used.

Calibration, as opposed to operational checks, was performed at all reactor plants. In-place calibration was the overwhelming method chosen. At three plants the calibration was performed elsewhere, namely the health physics laboratory. All plants but one had an external source or specially designed radioactive exposure device. The exception had a built-in radioactive check source. Approximately two-thirds (24) of the PWRs but only 36 percent of the BWRs used a combination of a radioactive source and electronic calibration.

RAM systems were not always calibrated after maintenance was performed. Three-fourths of the respondents (41) reported that calibration was always done after maintenance, and another four plants (7\%) reported that post maintenance calibration was done only on some RAM systems. One respondent noted that whether calibration was performed was dependant on the type of maintenance work that had been done. Four plants $(7 \%)$ reported that calibration was not done after maintenance; five declined to answer.

Specific calibration or operations tests and the number of plants where this is performed are given in Table 13. This table is only semi-quantitative 
and should be used accordingly. For example, the small numbers of plants where batteries are checked may be attributed to the relatively small number of systems equipped with this feature. Similarly, while only 43 plants reported having RAMs in control room, 45 performed trip point tests in this location, suggesting that this test was performed on the readout for detectors located elsewhere in the plant. 
TABLE 13. Specific Calibration Functions Performed on RAMs by Plant Location

Spec if ic Operation

Number of Plants reporting RAMs in Specified Location

Meter indication or readout is calibrated to correspond to the radiation level measured by the radiation detector unit.

Background of the detector unit is checked to see if it is too high.

High level alarm trip points are checked to see that they

The radiation detector is checked to be sure it will provide a signal capable of indicating full scale reading on the meter readout before detector saturation occurs.

The high voltage power for the detector unit is checked and the voltage level is reset if necessary. operate at the proper trip point and that reset properly.

\section{Containment} sure it operates properly or is reset to the proper operating point.

The low level "keep-alive" source or circuit in the radiation detcetion unit is chccked and adjustes if necessary.

The RAM system is checked for operational stability by observing the response to a radioactive source or elec tronic signal over a specific period of time.

RAM system remote readouts or meter indications are set to correspond with the meter indication at the master control or power supply unit.

Remote alarm indications are checked for proper operation and to insure against fail with time or reset themselves if they are not supposed to.

Meter indications or readouts are adjusted to read minimum or zero when no detector signal is present or the RAM system has no operating power.

Batteries or storage cells for emergency operation are checked to see if they are in good condition.
47

45

30

45

32

Fuel Turbine Control Auxiliary

Handling

27

27

43

46

43

23

41

32

33

18

46

23

16

14

9 


\section{OPINIONS AND COMMENTS OF RESPONDENTS}

An optional series of five questions designed to elicit operational experiences and opinions from operating personnel was included at the end of the questionnaire. Three questions were check offs to determine how satisfactory the RAM systems were perceived as being. The other two were open-end free-form questions asking for desired additional capability or features of RAM systems. Answers to the optional questions were provided by 44 plants, or four-fifths of those participating in the survey. All BWR participants answered the optional questions, compared with 27 of the 38 PWRs.

Those responding were generally pleased with the performance of the RAMs in their plants. Only one of the BWR respondents was dissatisfied with the RAM system as compared with three dissatisfied PWR respondents. Low maintenance was reported by all but one BWR respondent and by most of the PWR respondents. Similarly, most respondents did not express a desire to change systems.

About half of these responding to the optional questions offered suggestions regarding additional features they deemed desirable. Several suggested recorders, digital readout, and more RAM heads or locations. Graphic or CRT readout and computer capability was also suggested by several plants. The most frequently mentioned desired feature was to have readouts in the health physics office. This feature was desired at seven plants, all PWRs. Other desired features included individual annunciators, distinctive alarms, multiplexing, gamma spectrum capability, simplicity, better environmental design (this from a plant respondent who was displeased with the performance of the plant's system), and an internal source to provide an off-zero reading. Several respondents also noted that upgrading of various RAM systems was in progress or planned. 


\section{ACKNOWLEOGEMENTS}

The authors wish to thank the staff of the 55 light-water power reactors with operating licenses who responded to the questionnaire. We also wish to acknowledge the assistance of:

- S. C. Hawley, PNL, in gathering, collating, and reviewing the data;

- E. L. Krueger, PNL/Whitman College, and Paut Liddell in developing and debugging the computer routine RAMQ used in this study; and

- Carrie Lindell and Jack Drexier, Battelle, Human Affairs Research Centers, in developing the questionnaire. 


\section{REFERENCES}

American National Standard Institute (ANSI). 1979. Performance Specifications for Reactor Emergency Radiological Monitoring Instrum. ANSI N320-1979, ANSI, New York, New York.

Lahti, G. P., et al. 1980. "Designing for Post Accident Radiologica? Conditions", Nuclear Safety Analys is Center, Report NSAC-17, Electric Research Institute, Palo Alto, California.

Nuclear Regulatory Commission (NRC). 1979. TMI-2 Lessons Learned Task Force Status Report and Short-Term Recommendations, Report NUREG-0578, NRC, Washington, D.C.

Nuclear Regulatory Commission (NRC). 1980. Instruments for Light-Water-Cooled Nuclear Power Plant Conditions During and Following an Accident. Regulatory Guide 1.97, Revision 2, November 6, 1980, NRC, Washington, D.C.

Selby, J. M., et al. 1974. Technologica1 Considerations in Emergency Instrumentation Preparedness, Phase IIA-Emergency Radiological and Meteorological Criteria for Reactors. U.S. Atomic Energy Commission Report BNWL-1635, Pac if ic Northwest Laboratory, Richland, Washington. 

APPENDIX A

QUESTIONNAIRE 
APPENDIX A

QUESTIONNAIRE

\section{Power Reactor Remote Area Monitoring Capabilities Survey QUESTIONNAIRE}

In this questionnaire you will be asked about RAM and the RAM system in your plant. The RAM and the RAM system are defined as:

RAM-Any individual stationary instrument or channel used for the purpose of ambient radiation monitoring.

RAM System-The sum total of all detectors, readouts, power supplies, computer interfacing, and other ancillary components used with a RAM.

\section{SECTION}

\section{Administrative}

1. Please supply the following information for your facility:

Name of facility

Mailing address

City and State

Zip Code

Telephone number!

2. Circle the type of facility

[1] BWR

[2] PWR

[3] GCR

3. What is the rated power in $\mathrm{MW}_{\text {th }}$ of your facility:

4. Name and title of person filling out this questionnaire: 
5. For each RAM system in your facility complete the following table utilizing the numeric codes below for manufacturer's name and month of installation.

Manufacturer's Name

[1] Ebertine

[2] General Atomic

[3] General Electric

[4] Kaman

[5] NMC

[6] Radeco/SA]

[7] Technical Associates

[8] Victoreen

[9] Westinghouse

[10] Other (specify)

\section{Month of Installation}

[1] January

[2] February

[3] March

[4] April

[5] May

[6] June

[7] July

[8] A.ugust

[9] September

[10] October

[11] November

[12] Clecember

\begin{tabular}{|c|c|c|c|}
\hline Manufacturer & $\begin{array}{c}\text { Model } \\
\text { Designation }\end{array}$ & $\begin{array}{c}\text { Month of } \\
\text { Installation }\end{array}$ & $\begin{array}{c}\text { Year of } \\
\text { Installation }\end{array}$ \\
\hline & & & 19 \\
\hline & & & 19 \\
\hline & & & 19 \\
\hline & & & 19 \\
\hline & & & 19 \\
\hline
\end{tabular}

6. Specify number of detectors of each type in the following buildings:

\begin{tabular}{|l|l|l|l|l|l|l|}
\hline & $\begin{array}{c}\text { Contain- } \\
\text { ment }\end{array}$ & $\begin{array}{c}\text { Auxil- } \\
\text { iary }\end{array}$ & $\begin{array}{c}\text { Fuel } \\
\text { Handling }\end{array}$ & $\begin{array}{c}\text { Turbine } \\
\text { Generator }\end{array}$ & $\begin{array}{c}\text { Control } \\
\text { Room }\end{array}$ & Other \\
\hline GM & & & & & & \\
\hline Scintillation & & & & & & \\
\hline Other Chamber & & & & & & \\
\hline
\end{tabular}


7. Are you presently updating or planning to update your system? (other than required by NUREG 0578?)

[1] Yes

[2] No (if no, go to question \#9)

8. Are you presently updating or planning to update your system because of:
a. Regulatory requirement
[1]
[2]
$2: 66$
b. Exceeded design lifetime
[1]
[2]
2:67
c. Excessive maintenance
d. Inadequate capability
e. Other (specify)

\section{SECIION III}

\section{Design Features}

9. Please give the range(s) for the RAM system(s) used in the building listed, as applicable, specifying the units the system reads out in (e.g., $0.1 \mathrm{R} / \mathrm{hr}$ to $10^{6} \mathrm{R} / \mathrm{hr} ; 10^{3} \mathrm{mrad} / \mathrm{hr}$ to $10^{6} \mathrm{rad} / \mathrm{hr}$ ).
a. Containment
to

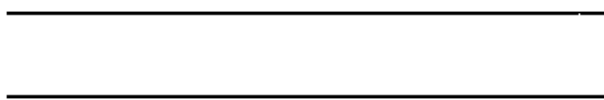
b. Auxiliary to
c. Fuel Handling to
d. Turbine Generator to
e. Control Room to

10. Does your RAM system(s) in containment have the following features:

a. Local readout

b. Read

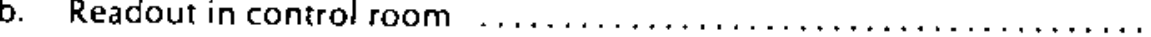

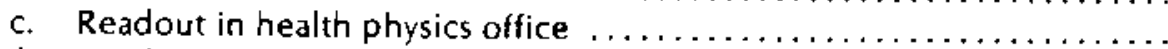

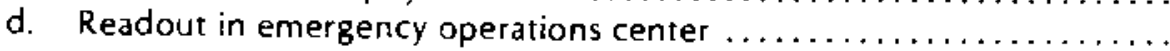

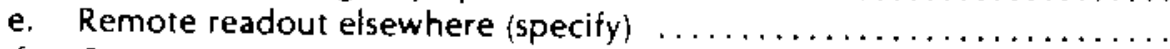

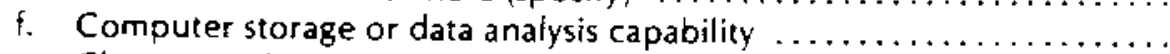

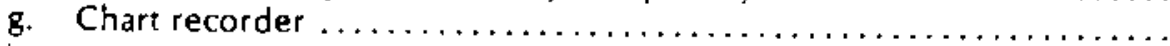

h. Meets requirements of NUREG 0578

$\begin{array}{ccc}\text { Yes } & \text { No } & \\ {[1]} & {[2]} & 3: 52 \\ {[1]} & {[2]} & 3: 53 \\ {[1]} & {[2]} & 3: 54 \\ {[1]} & {[2]} & 3: 55 \\ {[1]} & {[2]} & 3: 56 \\ {[1]} & {[2]} & 3: 57 \\ {[1]} & {[2]} & 3: 58 \\ {[1]} & {[2]} & 3: 59\end{array}$

11. RAM system readout is:

[1] Logarithmic

[2] Digital

[3] Multiscale linear

[4] Other (specify) 


\begin{tabular}{|c|c|c|}
\hline & Yes & No \\
\hline 2a. Do you have a local (near derector) high level alarm(s)? & {$[7]$} & $\begin{array}{c}\cdot[2] \\
\text { (if no, go to }=13 \mathrm{a})\end{array}$ \\
\hline Does the : & {$[1]$} & [2] \\
\hline
\end{tabular}

12c. On the following table check all visible signals produced by your local high level alarm(s):

\begin{tabular}{|l|l|l|l|l|l|}
\hline & Red & Magenta & $\begin{array}{l}\text { Yellow/ } \\
\text { Orange }\end{array}$ & White & Other \\
\hline Flashing or rotating light & & & & & \\
\hline Steady light & & & & & \\
\hline $\begin{array}{l}\text { Pilot light on } \\
\text { control panel }\end{array}$ & & & & & \\
\hline
\end{tabular}

13a. Do you have a high level alarm in the control room?

13b. Does the alarm(s) produce an audible signat?

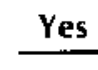

$[1]$

$[1]$

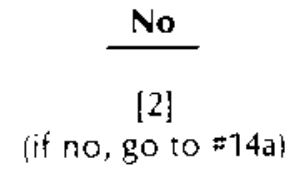

[2]
$3: 78$

$\underline{3.79}$

13c. On the following table check all visible signals produced by your high level alarmis in the control room:

\begin{tabular}{|l|l|l|l|l|l|}
\hline & Red & Magenta & $\begin{array}{l}\text { Yellow/ } \\
\text { Orange }\end{array}$ & White & Other \\
\hline Flashing or rotating light & & & & & \\
\hline Steady light & & & & & \\
\hline $\begin{array}{l}\text { Pilot light on } \\
\text { control panel }\end{array}$ & & & & & \\
\hline
\end{tabular}

$\underline{\text { Yes }} \quad$ No

14a. Do you have a high level alarmis) in the health physics office?

14b. Does the alarm(s) produce an audible signal?
[1]

[1]
[2] (if no. go to $=15 \mathrm{a}$ )

[2]
$4: 20$

4.21

\section{A. 4}


14c. On the following tabie check all visible signals produced by your high level alarm(s) in the health physics office:

\begin{tabular}{|l|l|l|l|l|l|}
\hline & Red & Magenta & $\begin{array}{l}\text { Yellow/ } \\
\text { Orange }\end{array}$ & White & Other \\
\hline Flashing or fotating light & & & & & \\
\hline Steady light & & & & & \\
\hline $\begin{array}{l}\text { Pilot light on } \\
\text { control panel }\end{array}$ & & & & & \\
\hline
\end{tabular}

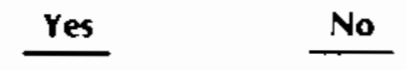

15a. Do you have a high level alarm(s) in the emergency operations center?

15b. Does the alarm(s) produce an audible signal?

15c. On the following table check all visible signals produced by your high leve alarm(s) in the emergency operations center:

\begin{tabular}{|l|l|l|l|l|l|}
\hline & Red & Magenta & $\begin{array}{l}\text { Yellow/ } \\
\text { Orange }\end{array}$ & White & Other \\
\hline Flashing or rotating light & & & & & \\
\hline Steady light & & & & & \\
\hline $\begin{array}{l}\text { Pilot light on } \\
\text { control panel }\end{array}$ & & & & & \\
\hline
\end{tabular}

16a. Do you have high level alarms throughout the plant?

16b. Do the alarms produce audible signals?

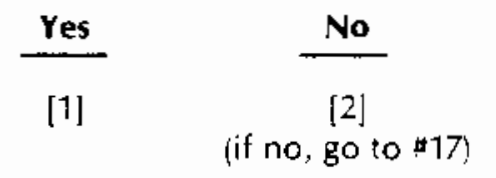

[1]
$[2]$
$4: 54$

4:55

\section{A. 5}


16c. On the following table check all visible signals produced by your high level alarms throughout the plant:

\begin{tabular}{|l|l|l|l|l|l|}
\hline & Red & Magenta & $\begin{array}{l}\text { Yellowi } \\
\text { Orange }\end{array}$ & White & Other \\
\hline Flashing of rotating light & & & & & $4: 45 \cdot 4: 60$ \\
\hline Steady light & & & & & \\
\hline $\begin{array}{l}\text { Pilot light on } \\
\text { control panel }\end{array}$ & & & & & \\
\hline
\end{tabular}

Yes $\quad$ No

17. Does the high level radiation alarm(s) stay on even when the radiation level drops below the trip point?

18. Do you have an intermediate level alarm?

19. Are any of the following used to maintain a positive instrument reading?
a. Internal radioactive source
[1]
[2]
$4: 73$
b. Background radiation leve
[1]
[2]
$4: 74$
c. Electronic
[1]
[2]
4:75
d. Other (specify)
[1]
[2]
4:76

\section{SECTION IV Operations}

20. How frequently are routine operational checks performed for each of the following locations:

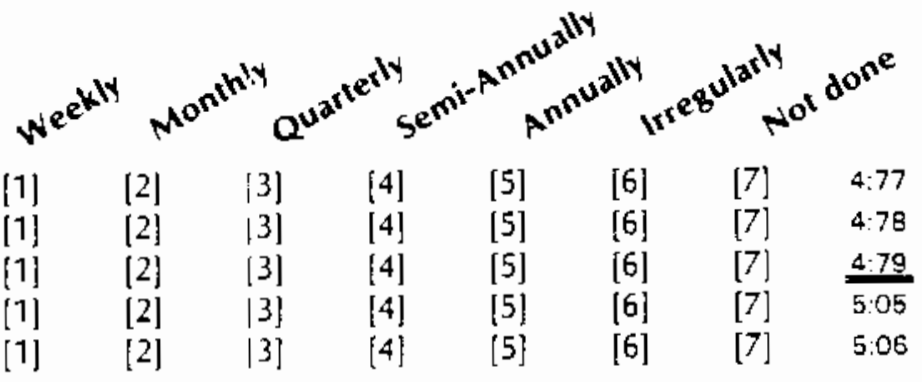


21. Check any locations at which the following routine operational checks are performed:
a. Internal radioactive check source to temporarily activate the detector
b. External radioactive check source (used manually)
c. Electronic (interna! test circuit)
d. Electronic (light source)
e. Electronic (external signal generator!
†. Visual inspection
g. Other (specify)
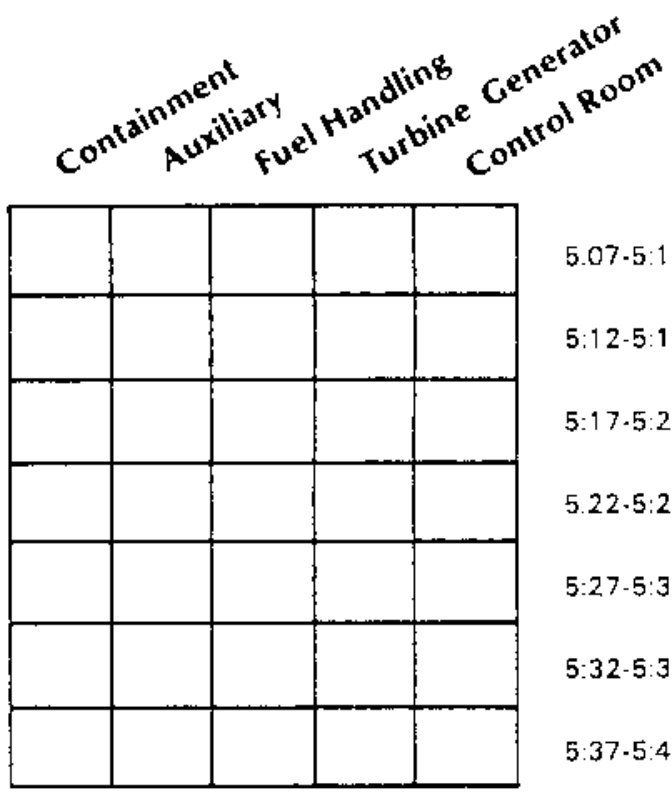

$5.07 \cdot 5: 11$

5:12-5:16

$5: 17 \cdot 5: 21$

$5.22 \cdot 5: 26$

5:27-5:31

5:32-5:36

5:37.5:41

22. Calibration is performed:

\begin{tabular}{ccc} 
Yes & No & \\
\cline { 3 - 3 }$[1]$ & {$[2]$} & $5: 42$ \\
{$[1]$} & {$[2]$} & $5: 43$ \\
{$[1]$} & {$[2]$} & $5: 44$ \\
{$[1]$} & {$[2]$} & $5: 45$ \\
{$[1]$} & {$[2]$} & $5: 46$
\end{tabular}

A. 7 
23. Check any locations at which the following RAM system calibration procedures are performed:

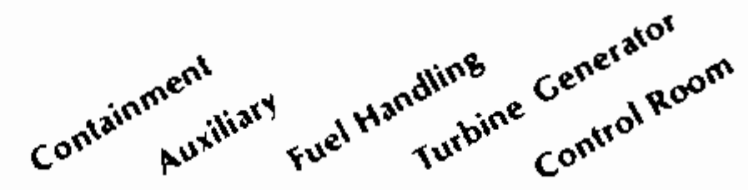

a. The meter indication or readout is calibrated to correspond to the radiation level measured by the radiation detector unit.

b. The radioactive background of the detector unit is checked to see if it is too high.

c. The high level alarm trip points are checked to see that they operate at the proper trip point and that they reset properly.

d. The radiation detector is checked to be sure it will provide a signal capable of indicating fuil scale reading on the meter readout before detector saturation occurs.

e. The high voltage power for the detector unit is checked and the voltage level is reset if necessary.

f. The low level radiation or fail alarm is checked to be sure it operates properly or is reset to the proper operating point.

g. The low level keep alive source or circuit in the radiation detection unit is checked and adjusted if necessary.

h. The RAM system is checked for operational stability by observing the response to a radioactive source or electronic signal over a specific period of time.

i. Any RAM system remote readouts or meter indications are set to correspond with the meter indication at the master control or power supply unit.

j. Remote alarm indications are checked for proper operation and to insure that they don't fail with time or reset themselves if they are nor supposed to.

k. Meter indications or readouts are adjusted to read minimum or zero when no detector signal is present or the RAM system has no operating power.

I. Any batteries or storage cells for emergency operation are checked to see if they are in good condition.

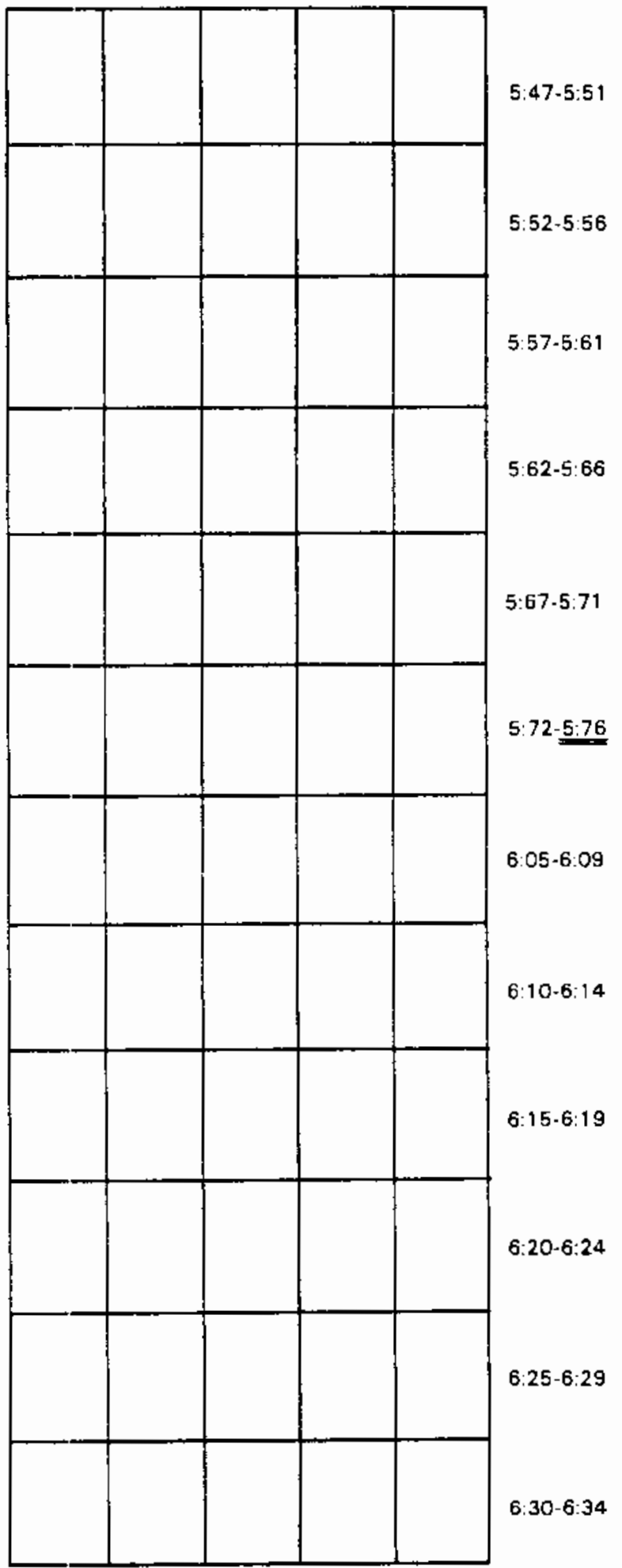

A. 8 
[1] Yes for all RAM systems

[2] Yes for some RAM systems

[3] No for none of the RAM systems

\section{SECTION VI}

\section{Optional}

This section of the questionnaire is voluntary. The purpose of this section is to obtain information in the form of opinions and experiences from operational personnel.

25. RAM facilities in my facility perform

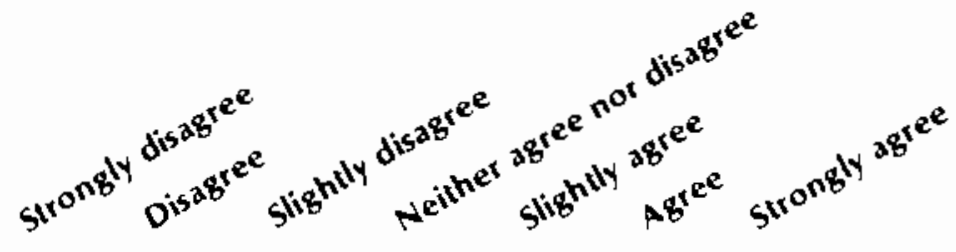
satisfactorily

$[\uparrow]$

[2] \{3\}

[4]

(5)

[6]

$[7]$

$6: 36$

26. The RAM system \{s\} in my facility operates with minimal maintenance

27. I would prefer to have a different RAM system(s) installed in my facility

28. What additional features, ranges, or changes would you like to see in the RAM system\{s\} at your facility?

29. What other features, changes, or adaptations do you think should be incorporated in all RAM systems used at all facilities similar to yours? 

APPENDIX B

SAMPLE COVER LETTER FOR QUUESTIONNAIRE 


\author{
August 18,1980
}

Telex 15-2874

Dear

Under contract to the United States Nuclear Regulatory Commission, Battelie is conducting a survey of the capabilities of installed remote area monitoring systems (RAMS) in nuclear power generating stations. To accomplish this task in an economical fashion and with a minimum of interruption for the plant staffs, a detailed questionnaire has been designed. This questionnaire should be easily completed by a knowledgeable person in 30 to 45 minutes.

Piease pass the questionnaire along to an appropriate member of your organization (the radiation protection manager is suggested) and have that person complete the questionnaire and return it in the enclosed, preaddressed postage paid envelope no later than September 10. The information will be tabulated and analyzed, and the results published.

Thank you for your assistance and cooperation.

Sincere ly yours,

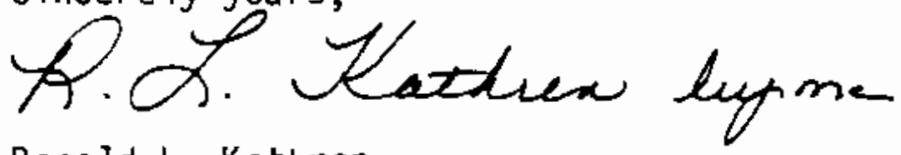

Ronald L. Kathren

Project Manager

br

enc losure 



\section{APPENDIX C \\ REACTOR RESPONDENTS PARTICIPATING IN THE STUDY}


APPENDIX C

REACTOR RESPONDENTS PARTICIPATING IN THE STUDY

Facility Name

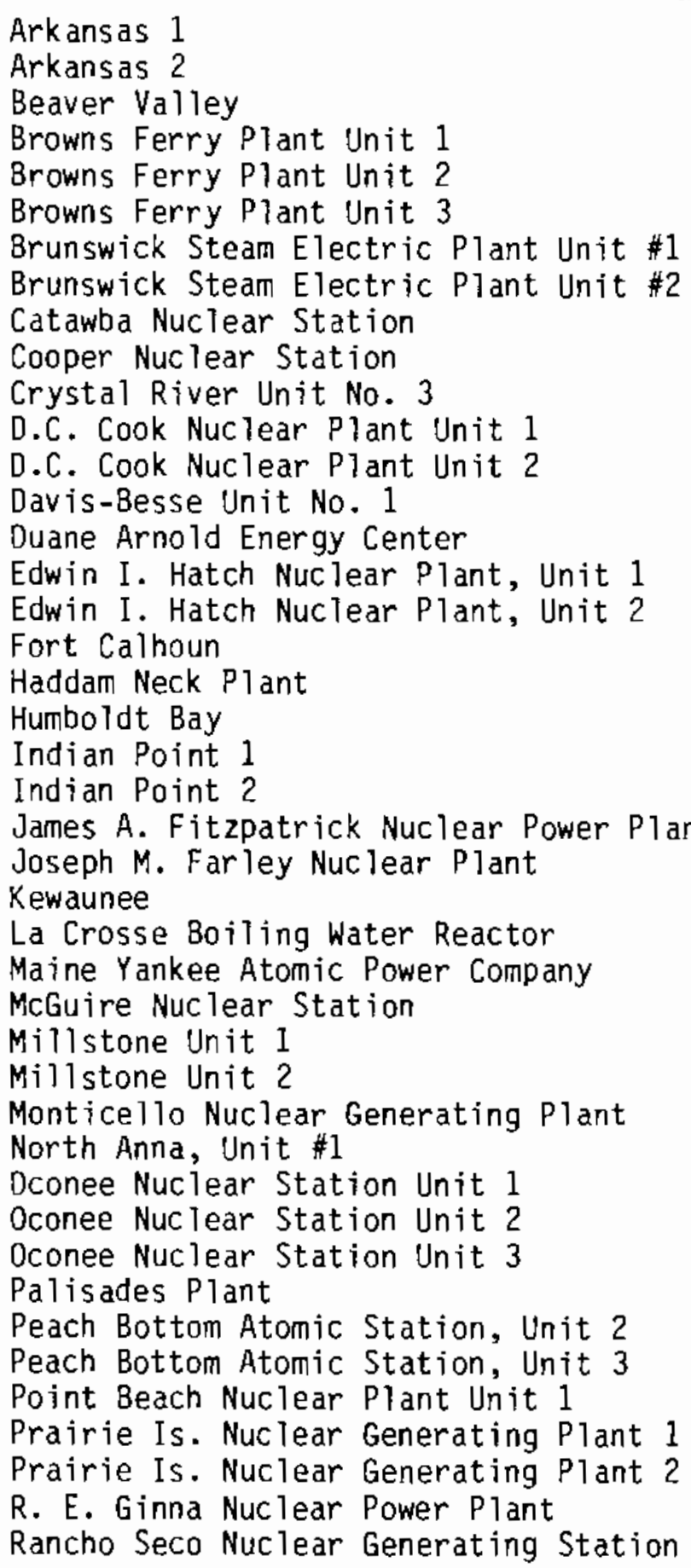

Plant Type

PWR

PWR

PWR

BWR

BWR

BWR

BWR

BWR

PWR

BWR

PWR

PWR

PWR

PWR

BWR

BWR

BWR

PWR

PWR

BWR

PWR

PWR

BWR

PWR

PWR

BWR

PWR

PWR

BWR

PWR

BWR

PWR

PWR

PWR

PWR

PWR

BWR

BWR

PWR

PWR

PWR

PWR

PWR 

Robinson 2

Salem \#1

St. Lucie 1

Surry Nuclear Power Station

PWR

PWR

PWR

Three Mile Island, Unit 1

Trojan Nuclear Plant

Turkey Point, Unit 3

Turkey Point, Unit 4

PWR

PWR

PWR

PWR

PWR

Vermont Yankee Nuclear Power Station

BWR

Yankee-Rowe Atomic Power Station

PWR

Zion 1

Zion 2

PWR

PWR 

NUREG/CR-2413

PNL-4106

$\mathrm{RH}$

\section{DISTRIBUTION}

No. of

Copies

OFFSITE

A. A. Churm

OOE Chicago Patent Group

9800 South Cass Avenue

Argonne, IL 60439

25 U.S. Nuclear Regulatory Commission

Division of Technical Information and Document Contro?

7920 Norfolk Avenue

Bethesda, MA 20014

30 Seymour Block

Nuclear Reactor Regulation

U.S. Nuclear Regulatory Commission

Washington, D.C. 20555

Doug Collins

Nuclear Reactor Regulation

U.S. Nuclear Regulatory

Comission

Washington, D.C. 20555

Frank Congel

Nuclear Reactor Regulation

U.S. Nuclear Regulatory Commission

Washington, D.C. 20555

William Kreger

Nuclear Reactor Regulation

U.S. Nuclear Regulatory

Commission

Washington, D.C. 20555
No. of

Copies

Roger Mattson

Nuclear Reactor Regulation

U.S. Nuclear Regulatory Commission

Wëshington, D.C. 20555

Spencer $C$. Stevens

Manager, Fort Calhoun Station

Omaha Public Power District

1623 Harney

Ornaha, NB 68102

2 DOE Technical Information Center

ONSITE

31 Pacific Northwest Laboratory

V. A. Benton

D. M. Fleming

W. A. Glass

R. L. Kathren (12)

J. L. Kenoyer

H. V. Larson

J. Laughlin

M. A. Mckinney

$\therefore$ B. Martin

F. P. Mileham (3)

i. M. Selby

Fublishing Coordination PC (2)

Technical Information (5) 



\begin{tabular}{|c|c|c|c|}
\hline \multicolumn{2}{|c|}{$\begin{array}{l}\text { NAC FORM 335 } \\
\text { (7.77) } \\
\text { BIBL NUCLEAR REGULATORY COMMISSION }\end{array}$} & \multicolumn{2}{|c|}{$\begin{array}{l}\text { 1. REPORT NUNBEA /Assigned bV DOCJ } \\
\text { NUREG/CR }-2413 \\
\text { PNL }-4106\end{array}$} \\
\hline \multicolumn{2}{|c|}{ 4. TITLE AND SUBTITLE (Add VolumA No, if appropriate) } & \multicolumn{2}{|l|}{ 2. (Leave biank) } \\
\hline \multicolumn{2}{|c|}{$\begin{array}{l}\text { Survey of Remote Area Monitoring Systems at U.S. } \\
\text { Light-Water-Cooled Power Reactors }\end{array}$} & \multicolumn{2}{|c|}{ 3. RECIPIENT'S ACCESSION NO. } \\
\hline \multirow{2}{*}{\multicolumn{2}{|c|}{$\begin{array}{l}\text { 7. AuthoR(s) } \\
\text { R. L. Kathren, A. P. Mi leham }\end{array}$}} & \multicolumn{2}{|c|}{ 5. DATE REPOAT COMPLETED } \\
\hline & & $\begin{array}{l}\text { MONTH } \\
\text { November }\end{array}$ & $\begin{array}{c}\text { YEAR } \\
1981\end{array}$ \\
\hline \multirow{2}{*}{\multicolumn{2}{|c|}{ 9. PERFOHMING ORGANIZATION NAME AND MAILING ADDRESS (include $Z_{i p}$ Code) }} & \multicolumn{2}{|c|}{ DATE REPORT ISSUED } \\
\hline & & $\begin{array}{l}\text { MONTH } \\
\text { April }\end{array}$ & \begin{tabular}{r|r|} 
YEAR \\
1982 \\
\end{tabular} \\
\hline \multirow{2}{*}{\multicolumn{2}{|c|}{$\begin{array}{l}\text { Pacific Northwest Laboratory } \\
\text { Richland, Washington } 99352\end{array}$}} & \multicolumn{2}{|l|}{ 6. (Leave blank) } \\
\hline & & \multicolumn{2}{|l|}{ 8. (Leave b/ank) } \\
\hline \multirow{2}{*}{\multicolumn{2}{|c|}{$\begin{array}{l}\text { 12. SPONSORING ORGANIZATION NAME AND MAILING ADORESS (Inc/ude ZiP Codg) } \\
\text { Division of SystemS Integration } \\
\text { Office of Nuclear Reactor Regulation } \\
\text { U. S. Nuclear Regulatory Commission } \\
\text { Washington, D.C. } 20555\end{array}$}} & \multicolumn{2}{|c|}{ 10. PHOJECT/TASK/WOAK UNITNO. } \\
\hline & & \multicolumn{2}{|c|}{$\begin{array}{l}\text { 11. CONTRACT NO. } \\
\text { NRC FIN B2174 }\end{array}$} \\
\hline \multicolumn{4}{|l|}{$\begin{array}{l}\text { 13. TYPE OF REPORT } \\
\text { Technical Information }\end{array}$} \\
\hline \multicolumn{2}{|l|}{ 15. SUPPLEMENTAAY NOTES } & \multicolumn{2}{|l|}{ 14. (Leave blank) } \\
\hline \multicolumn{4}{|c|}{$\begin{array}{l}\text { 16. ABSTRACr } 200 \text { words or lessl } \\
\text { A study was made of the capabilities and operating practices, including calibration, } \\
\text { of remote area monitoring (RAM) systems at light-water-cooled power reactors in the } \\
\text { United States. The information was obtained by mail questionnaire. Specific design } \\
\text { capabilities, including range, readout and alarm features are documented along with } \\
\text { the numbers and location of detectors, calibration and operational procedures. } \\
\text { Comments of respondents regarding RAB systems are clso included. }\end{array}$} \\
\hline 17. KEY WORDS AND DOCUMENT ANALYSIS & a. OESC & & \\
\hline \multicolumn{4}{|l|}{ 17D. IDENTIFIERS/OPEN-ENDED TEAMS } \\
\hline \multirow{2}{*}{$\begin{array}{l}\text { 18. AVAILABILITY STATEMENT } \\
\text { Unlimited }\end{array}$} & $\begin{aligned} \text { 19. SE } \\
\text { ln }\end{aligned}$ & $\begin{array}{l}\text { CLASS (This report) } \\
\text { ified }\end{array}$ & 21. NO. OF PAGES \\
\hline & & $\begin{array}{l}\text { CLASS (This pages } \\
\text { ified }\end{array}$ & $\begin{array}{l}\text { 22. PRICE } \\
\mathrm{S}\end{array}$ \\
\hline
\end{tabular}


